Revue belge de géographie

\title{
Town-twinning as a factor generating international flows of goods and people - the example of Poland
} Le jumelage des villes comme facteur d'impulsion à des flux internationaux de biens et de personnes. L'exemple de la Pologne

\section{Marek Furmankiewicz}

\section{(2) OpenEdition}

\section{Journals}

Electronic version

URL: http://journals.openedition.org/belgeo/12466

DOI: $10.4000 /$ belgeo. 12466

ISSN: 2294-9135

Publisher:

National Committee of Geography of Belgium, Société Royale Belge de Géographie

Printed version

Date of publication: 30 June 2005

Number of pages: 145-162

ISSN: 1377-2368

\section{Electronic reference}

Marek Furmankiewicz, "Town-twinning as a factor generating international flows of goods and people - the example of Poland", Belgeo [Online], 1-2 | 2005, Online since 27 October 2013, connection on 05 February 2021. URL: http://journals.openedition.org/belgeo/12466 ; DOI: https://doi.org/10.4000/ belgeo.12466

This text was automatically generated on 5 February 2021.

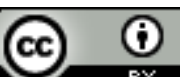

Belgeo est mis à disposition selon les termes de la licence Creative Commons Attribution 4.0 International. 


\title{
Town-twinning as a factor generating international flows of goods and people - the example of Poland
}

\author{
Le jumelage des villes comme facteur d'impulsion à des flux internationaux de \\ biens et de personnes. L'exemple de la Pologne
}

Marek Furmankiewicz

\section{Introduction}

Probably the first recorded twinning links in Europe were established in 1918 between Brugg, Switzerland and Rottweil, Germany (Casagrande, cited in Zelinsky, 1991) or in 1920 between Keighley, Great Britain and Poix du Nord, France (Handley, 2001). Following World War II, the concept of town-twinning spread all over the world and was used as an effective tool in the process of peace and reconciliation, bringing together countries which had previously been locked in combat. One of the symbols is the quoted case of Montbéliard (France) and Ludwigsburg (Germany) town-twinning established in the 1950s (Burger and Rahm, 1996; Brzozowska, 1998). In 1951, the Council of Municipalities of Europe (now Council of European Municipalities and Regions) was set up to support the idea of twinning relationships. Similarly, since 1956 sister-city relationships have been actively encouraged on a national scale in the United States, following President Dwight Eisenhower's call for "people-to-people diplomacy". Consequently the organisation Sister Cities International was established in 1967 (Zelinsky, 1991; Schep et al., 1995). Intensive development of this form of cooperation in Western Europe was noted in the 1970s and 1980s. In 1995, the European Union had more than 7 thousand bilateral relations involving almost ten thousand municipalities, mainly French (2837 municipalities) and German (2485) (Lücke and Bellocchi, 1997). Bilateral municipal cooperation also developed in Asia with special 
activity of Japanese local governments (Schep et al., 1995; Alger, 1997). After the Communist block break-up and the start of democratic change in Central and Eastern Europe, countries in this area joined in the twinning process. Partners from developed, democratic countries sought to encourage the growth of democracy and free market economy in the region (Handley, 2001). In Poland, international agreements of cities also appeared from 1950s, although until 1989 all the contacts were under control and restricted for ideological reasons by communist authorities. Only after the political transformation in 1989-90, the spontaneous and voluntary development of cooperation between local authorities began (Koćwin, 1993; Furmankiewicz, 2001).

2 The establishment of international contacts between local authorities as part of different kinds of Municipal International Cooperation (MIC), like bilateral relations between municipalities (town-twinning, sister-cities), border associations and big international organizations is one of the facets of the ongoing globalization, of which the European integration is part. These links enable local communities to share experience and innovation in the field of town and municipality management techniques and encourage people to follow the tendency to remove political barriers. Additionally, they generate flows of goods and people as part of exchange programmes initiated by local governments and organized with their assistance. MIC is used to facilitate the exchange of technical expertise, to provide staff training and development, to address issues of racism and social inclusion, to find solutions to environmental problems or to enhance the education attainment of young people (Handley, 2001). International exchange programmes can play an important role in building a more participatory world. They offer many opportunities for personal experience in transnational systems, thereby helping to break down perceptual gaps (Alger, 1981, 1999). One of the most important instruments for achieving these aims is municipal exchange of officials and citizens (especially children and youth).

3 The purpose of this paper is to speculate about twinning exchange programmes in the context of international human mobility. The paper deals with three main issues: (1) The role of different factors in establishing and enhancing exchange; (2) Obstacles to exchange; (3) The material and non-material results of exchange. On the other hand, it is interesting to see if the development of the twinning agreements with Polish municipalities is a result of human mobility and only enhances the existing links or whether it really generates them.

\section{Materials and methods}

4 In Poland, international agreements of local governments have been officially registered by the Ministry of International Affairs only since 2001, but their current list is incomplete. A better list has been compiled by the Association of Polish Cities, which in January 1998 and at the end of 2000 conducted research into the state of development of international cooperation of towns and municipalities across Poland (Brzozowska, 1998; Hałas and Porawski, 2003). This and other data from a few regional reports or publications have been used to conduct a poll. Considerable divergences in the lists of twinned towns in Poland based on different sources show that we must look extremely prudently at the absolute value of the data and consider only the general character of international connections. 
5 In 2002, the author sent out a questionnaire to 754 Polish municipalities (rural, urbanrural and urban) having foreign partners according to this data. As a result, 240 municipalities answered and reported about 448 partnerships, 20 municipalities answered that they currently had no foreign partners, and 46 networks were verified as no longer existing. Thus, accurate answers were obtained about 402 twinnings of 220 Polish municipalities.

6 International cooperation of municipalities located up to $100 \mathrm{~km}$ from the state border, and no more than $200 \mathrm{~km}$ from one another, was described as border (transborder) cooperation. In other cases, international cooperation of municipalities was described as transregional. This division enables showing and comparing the main features of border exchange and the exchange involving cities located in central Poland.

7 All the cooperating municipalities were asked to fill in a questionnaire about at least two most effective examples of bilateral cooperation. The subjects were able to give more than one answer to each question (for this reason the distinguished categories do not sum up to $100 \%$ ). The results were analysed in percentage terms. The poll included the following questions:

-Who was responsible for creating the twinning relations?

- What material (goods and infrastructural investments) and non-material (knowledge and information) flows resulted from the twinning relations?

- Are twinning arrangements supported by any institution/foundation/programmes?

- Are there any barriers limiting cooperation conducted by Polish municipalities?

- What are the future plans of Polish local governments engaged in the twinning relations?

Based on the answers to this poll, I discuss the conditions which produced the dimension of cooperation and characteristic of mobility resulting from town-twinning, the scale and direction of this mobility, as well as the social, economic, environmental, cultural and political implications of exchange. It is also interesting to answer the question of whether the town-twinning connections result from human mobility or generate this mobility.

9 The effects of cooperation listed by the respondents were divided into non-material ones (gaining knowledge and information, also in the process of human exchange), and material ones (purchase of equipment, common investment, material gifts). Financial resources were classified according to the goals which they were used for, e.g. if the resources were used for spatial planning or development strategy, they were placed in the first category. If they were used to finance the building and equipping of offices, schools, or cultural centres, they were classified as material effects.

10 The first part of the paper shows the historical development of twinning in Poland and describes the current state of connections. Furthermore, the most important factors influencing the choice and the establishment of bilateral partnerships, as well as the obstacles to cooperation are analysed. In the next part of paper the material and nonmaterial effects of cooperation are shown, with special attention given to people and goods exchange. Finally, the reasons for the level and the direction of the exchange are analysed. 


\section{Town-twinning in Poland}

11 During the Communist period (1945-1989) there were no autonomous local governments, having legal status and powers specified by law. All municipal units and their authorities were part of the central government (Grochowski and Regulska, 2000). Additionally, citizens had no possibility to travel abroad freely, which limited international contacts and the MIC development.

Since the mid-fifties, the authorities of the largest Polish towns were allowed to initiate contacts with towns in Communist countries: Bulgaria, Czechoslovakia, the GDR or the USSR. In these contacts, cooperation focused mainly on ideological goals, was organised top-down and was controlled by representatives of the central government (voivodes). The reports from meetings of Polish delegations with those from other Communist-bloc countries included such topics as "socialist formation of youth", "methods of Party control of socio-economic and political life", "using the experience of sister parties in mastering the activities of Party organisations" or "achievements and problems of building socialism" (Trzcielińska-Polus, 1997). Most of these contacts involved only meetings of officials and Communist Party activists. The lists of exchange participants were authorised by the Voivodeship (regional) Committees of the Polish United Workers' Party. There were only a few agreements with cities in Western Europe, mainly in Finland, which was under the political influence of the USSR.

In the 1970s, the "policy of openness" provided opportunities for limited networking with towns in the democratic ("capitalist") countries of Western Europe, mainly in Finland, Great Britain and Western Germany. In general, however, only limited youth exchange was possible (Laurent, 1991). Such contacts were still under central government control. There was often no real cooperation of the "appointed" towns (Koćwin, 1993).

14 The closure of borders due to the political crisis in the early eighties, including the introduction of Martial Law (1981-1982), caused all contacts to vanish, but after 1983 the cooperation slowly returned to the level from before 1980. In this period, contacts were generally limited to officials and legal organisations (e.g. Scout exchanges with the USSR) in the Communist bloc. W. Zelinsky (1991) reports nearly 117 bilateral agreements of Polish municipalities with partners in 26 countries in 1988.

As a result of political transformations in 1989/1990, after the first democratic local authority elections, municipalities became self-determining legal units. Since that time, international contacts could have been developed freely in a formal way with the wide participation of common citizens, and consequently the number of established agreements has grown spontaneously (see Figure 1). Most of them were new relations but in some cases former contacts were renewed (Markowiak, 1997; Furmankiewicz, 2001). 
Figure 1. The year of the first official contact or agreement with the foreign partner in the existing bilateral partnerships of Polish municipalities (for the 1735 partnerships giving this information).

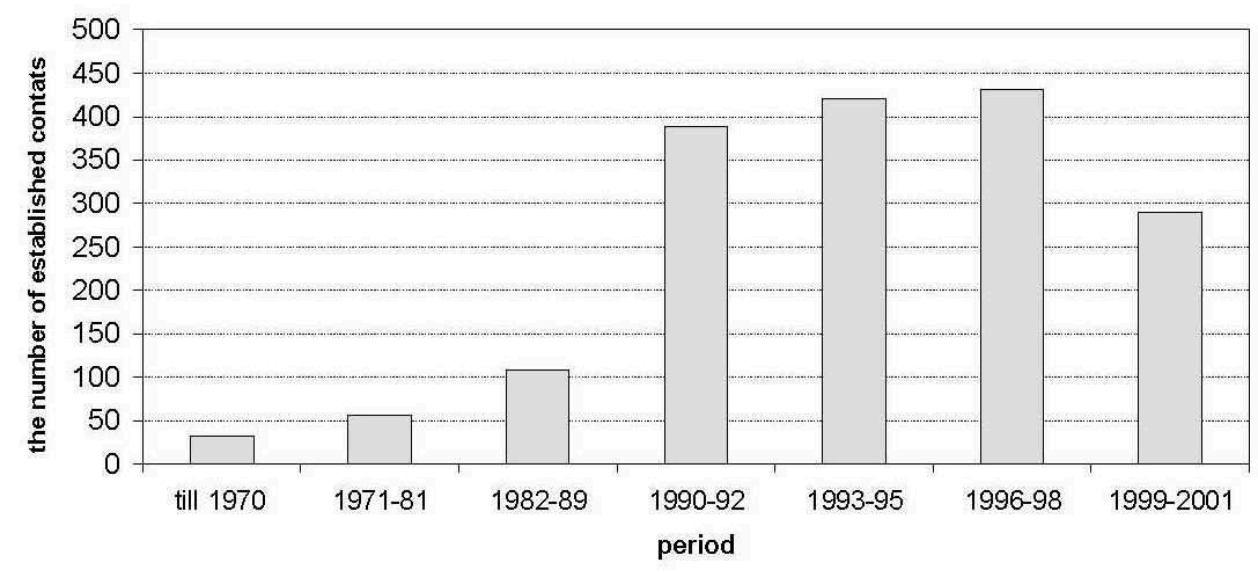

SOURCE: AUTHOR'S OWN CALCULATIONS BASED ON DATA FROM THE ASSOCIATION OF POLISH CITIES AND OTHER MATERIALS.

In 1993, Poland ratified the European Outline Convention on Transfrontier Cooperation between Territorial Communities or Authorities, announced in Madrid on $21^{\text {st }}$ May, 1980, and in 1994 it ratified the European Charter of Local Self-Government, signed in 1985 by 12 countries participating in the work of the Standing Conference of Local and Regional Authorities of Europe (currently Congress of...).

In the period 1990-2000, local governments had much freedom in establishing contacts, and used this opportunity for para-diplomacy. For instance, in 1997, the local government of Kraków made an agreement with Grozny in Russia to show their support of the Chechnya independence idea (Kwiatek-So ${ }^{3}$ tys, 2002).

In 2001 the Law of 15 September 2000 concerning the principles of joining international associations of local and regional communities by units of territorial self-government came into force (Dziennik Ustaw No 91 of 28.11.2000, pos. 1009). The law states that units of territorial self-government can join associations and take part in them in the range limited by their tasks and powers, in compliance with Polish law, the international policy of Poland and its international commitments. According to the law, the minister of foreign affairs agrees to join an association by a unit of territorial self-government or opposes it through an administrative decision. In the case of lack of consent to further membership, the unit has to leave the association.

According to my research, at the end of 2001, there were at least 2153 active partnership relations between 734 Polish local governments and foreign partners. The foreign twin towns were mainly from European countries (95.8\%). Most partners were from Western Europe (53.1\%), chiefly from Germany, France and Holland. Partners from Central Europe followed (19.3\%, mainly from the Czech Republic, Slovakia and Hungary). Links of Polish municipalities with Austria and Switzerland were also weak, although these countries are holiday destinations for numerous Poles, and in the case of Austria - also a workplace. There were also fewer contacts with municipalities from Eastern Europe (former Soviet Union and Romania), i.e. 11.8\%. In this group partners from Ukraine, Lithuania and Russia dominated. There were also a few insignificant contacts with Scandinavian countries (mainly Denmark and Sweden). Polish local 
governments have the fewest relations with Mediterranean countries (mainly Italy and Spain).

Outside Europe, the cooperation with partners from North America and Asia dominated. Contacts with North America concerned solely municipalities from the USA (more than $47 \%$ of all links with non-European partners). As for the number of contacts, links with the USA, despite the significant costs of establishing relationships, were only slightly weaker than those with Italy. There were more partners from Mexico and Chile than from Portugal or Greece, and almost as many as from Spain. Municipalities from Israel and China dominated in cooperation with Asia.

Table 1. Origin of European partners of Polish municipalities at the end of 2001.

\begin{tabular}{|l|c|l|}
\hline \multicolumn{1}{|c|}{ Part of Europe } & $\begin{array}{c}\text { Percentage [\%] of all } \\
\text { European partners }\end{array}$ & \multicolumn{1}{c|}{ Main countries } \\
\hline Western Europe & $\mathbf{5 3 , 1}$ & Germany, France, Holland \\
\hline Central Europe & $\mathbf{1 9 , 6}$ & $\begin{array}{l}\text { Czech Republic, Slovakia, } \\
\text { Hungary }\end{array}$ \\
\hline $\begin{array}{l}\text { Eastern Europe (including the whole of } \\
\text { Russia) }\end{array}$ & $\mathbf{1 1 , 8}$ & Ukraine, Lithuania, Russia \\
\hline Scandinavia & $\mathbf{1 0 , 8}$ & Denmark, Sweden \\
\hline $\begin{array}{l}\text { The Mediterranean and the Balkans (without } \\
\text { France and with former Yugoslavia) }\end{array}$ & $\mathbf{4 , 7}$ & Italy, Spain \\
\hline
\end{tabular}

SOURCE: AUTHOR'S OWN CALCULATIONS BASED ON DATA FROM THE ASSOCIATION OF POLISH CITIES AND OTHER MATERIALS

Table 2. Origin of foreign partners of Polish municipalities according to continents at the end of 2001.

\begin{tabular}{|l|c|c|}
\hline \multicolumn{1}{|c|}{ Continent } & Percentage [\%] of all partners & Main countries \\
\hline 1. Europe (incl. whole of Russia) & $\mathbf{9 5 , 8}$ & Germany, France \\
\hline 2. North America & $\mathbf{2 , 0}$ & USA \\
\hline 3. Asia & $\mathbf{1 , 6}$ & Israel, China \\
\hline 4. Latin America & $\mathbf{0 , 6}$ & Mexico \\
\hline 5. Africa & $\mathbf{0 , 0}$ & Morocco \\
\hline
\end{tabular}

SOURCE: AUTHOR'S OWN CALCULATIONS BASED ON DATA FROM THE ASSOCIATION OF POLISH CITIES AND OTHER MATERIALS

Table 3. Origin of foreign partners of Polish municipalities according to countries at the end of 2001.

\begin{tabular}{|l|c|c|}
\hline \multicolumn{1}{|c|}{ Origin of foreign partners } & Number & Percentage [\%] \\
\hline 1. Germany & 644 & $\mathbf{3 0 , 0}$ \\
\hline 2. France & 208 & $\mathbf{9 , 6}$ \\
\hline 3. Czech Republic & 174 & $\mathbf{8 , 1}$ \\
\hline 2. Holland & 144 & $\mathbf{6 , 7}$ \\
\hline 4. Denmark & 116 & $\mathbf{5 , 4}$ \\
\hline 5. Slovakia & 101 & $\mathbf{4 , 7}$ \\
\hline 6. Hungary & 89 & $\mathbf{4 , 1}$ \\
\hline 7. Ukraine & 81 & $\mathbf{3 , 8}$ \\
\hline 8. Sweden & 80 & $\mathbf{3 , 7}$ \\
\hline 9. Great Britain & 67 & $\mathbf{3 , 1}$ \\
\hline 10. Lithuania & 66 & $\mathbf{3 , 1}$ \\
\hline The others & 383 & $\mathbf{1 7 , 7}$ \\
\hline Total & 2153 & $\mathbf{1 0 0}$ \\
\hline
\end{tabular}

SOURCE: AUTHOR'S OWN CALCULATIONS BASED ON DATA FROM THE ASSOCIATION OF POLISH CITIES AND OTHER MATERIALS 
Figure 2. The percentage of border links in the total number of Polish municipalities' partnerships with partners from neighbouring countries.

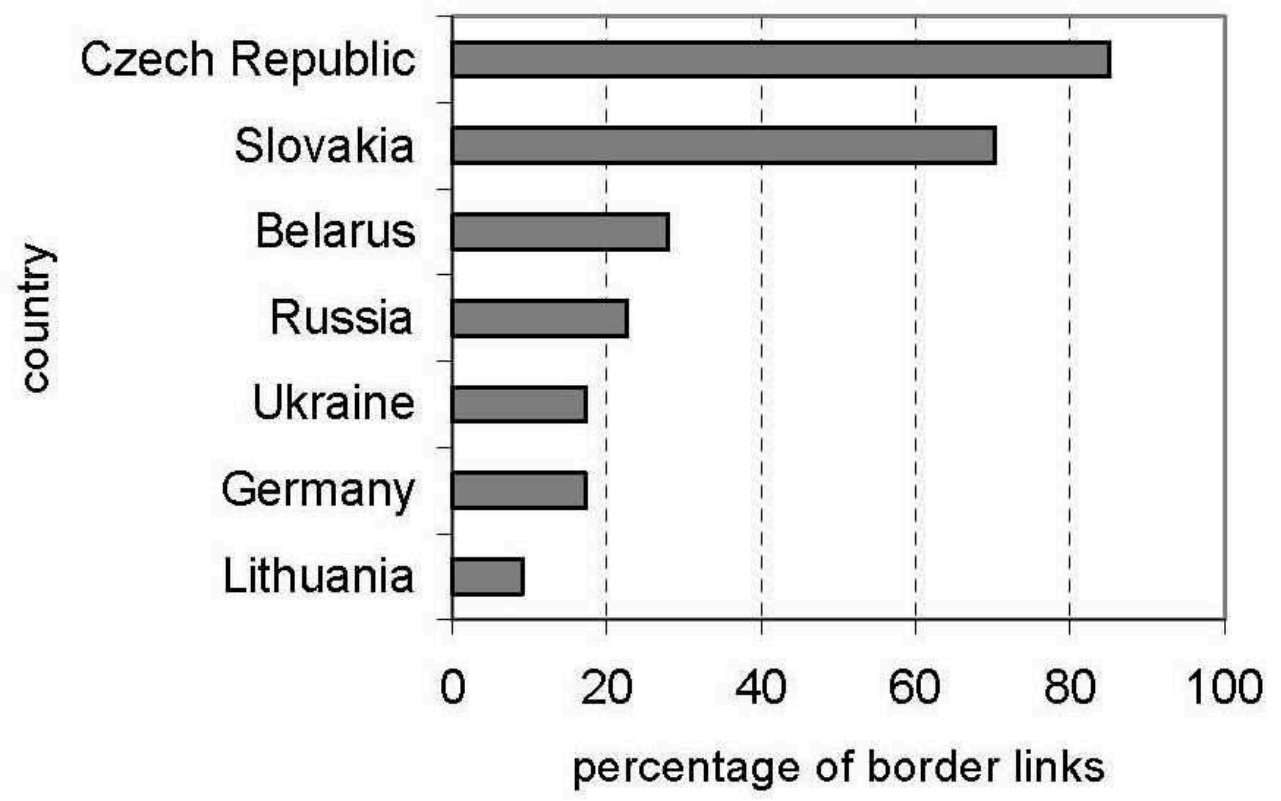

Source: Author's own calculations

Among international connections of Polish municipalities, the percentage of border twinnings is the highest in the cooperation with Czech (85\% of all links) and slovak partners (70\%) (Figure 2). This shows the border character of these contacts. In the case of cooperation with Lithuania, only $9 \%$ of twinning links have a border character, and with Germany and Ukraine, only $17 \%$ in either case. The absolute number of border twinnings includes the most links with partners from the Czech Republic (at least 149 links), Germany (111 links) and Slovakia (71 links). The number of twinning border links on the eastern border of Poland is much lower.

In 2001 Krakow was involved in the greatest number of partnerships (a total of about 40 partners, but only 22 active twinnings), followed by Gdańsk (17 twinnings) and Łódź (15). These cities achieved several projects with international cooperation and supported by international institutions. The Polish capital city Warsaw was involved in about 12 twinnings, though less advanced if compared with the activity of smaller regional centres in Poland (Furmankiewicz, 2002). Many medium towns proved more efficient in individual partnerships and were granted different kinds of awards, e.g. the "Golden Stars of Town-twinning" award for their successful contribution to European integration and for bringing European citizens closer together (Hałas and Porawski, 2003).

\section{Establishment of twinning}

In answering the question about factors that positively influenced the establishment of bilateral partnerships, municipalities listed most frequently private contacts ( $45 \%$ of all respondents), support of external institutions (32\%) and local institutions (20\%). These categories had almost the same significance in border and transregional cooperation (Figure 3). 
Figure 3. Factors supporting the choice and establishment of town-twinning networks.

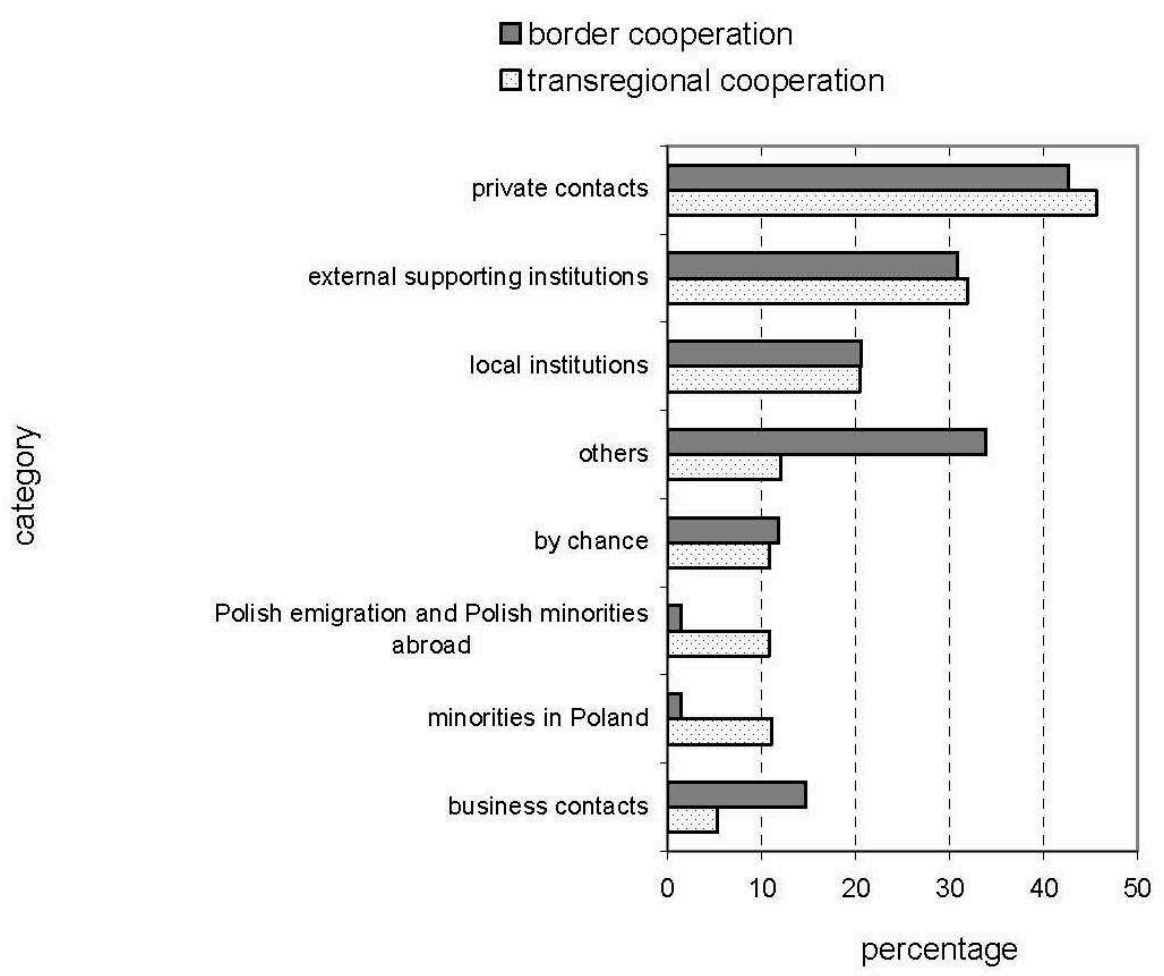

Source: the author's research

"Private contacts" were related mainly to the individual mobility of citizens, especially local leaders. The supporting external institutions were most frequently: the PolishGerman Cooperation Foundation and the European Commission offering assistance through support programmes like Phare-Crossborder in border regions, TownTwinning, Ecos-Overture, Youth for Europe and others. In the early 1990s help in connecting partners was offered by the Twinned Town Division of the Bureau of Councils of Ministers (Warsaw). Its aims were to support the ideas of regions, cities and towns cooperation. The Division offered help in seeking foreign partners and kept a data bank on town-twinning. Partners were matched on the basis of criteria such as geographical location, history, their function, cultural traditions, social and demographic features, the level of economic development, socio-economic problems and the cooperation range listed in the applications (Budzynowska, 1996). Towntwinning was also supported by the Local Democracy Development Foundation (Warsaw, Poland) in cooperation with municipality organisations in other European countries e.g. the Dutch Municipalities Association. The Association of Polish Cities helps Polish municipalities to apply for grants from the European Commission TownTwinning Programme. In border regions, euroregions and other foundations or agencies also offer municipalities their help in seeking individual partners (Marczuk and Palka, 2002).

Local institutions helping to establish international contacts were schools, nongovernmental organisation like local country-lovers' associations, public institutions like fire departments, culture centres and others. Interestingly, there was quite a large number of answers quoting "chance" as the reason for choosing the partner. One of the 
cases is establishing an official partnership after receiving help by a German delegation visiting another place in Poland, when their car broke down in the area of the chance municipality (Syców-Malch).

26 The "others" category was most frequently listed by municipalities in border regions, which pointed at territorial proximity, the necessity of opening new border-crossing points, solving the environmental problems of common functional space, or spatial development of areas divided by the state border. The least role in establishing partnerships had activity of Polish immigrants and Polish minorities abroad, as well as foreign minorities in Poland. Both groups had larger significance in transregional cooperation. Business contacts were listed more frequently in border contacts, but in general, they did not have a great significance in establishing twinning contacts.

\section{Obstacles to cooperation}

The main obstacle to cooperation, reported by local governments in Poland, was the lack of financial resources ( $42 \%$ of all answers), which limited the possibility of common meetings and citizen exchanges, considered the main aim of cooperation. The other categories were listed in smaller numbers, only by up to $10 \%$ of all respondents. One of the most important obstacles was personal change in the partner's local authorities. Sometimes new authorities are not interested in sustaining partnerships, especially when the results of cooperation are not significant or when the relations at a citizen level are not well developed. This similarly applies to the category "lack of partner's activity". These three main categories of (above-mentioned) obstacles had similar significance in border and transregional cooperation (Figure 4). 
Figure 4. The obstacles to bilateral international cooperation in Polish municipalities' opinion.

border cooperation

$\square$ transregional cooperation



SOURCE: THE AUTHOR'S OWN RESEARCH

In transregional international town-twinnings, the barriers to cooperation were "long distance" and difficulties in communication due to the lack of knowledge of the partner's language. The language barrier was less frequently listed in border connections. The "investment risk" means local authority's fear that the cost of cooperation and exchange will be inadequate to the effects of such activity. It was more frequently listed in border relations. Only $2.6 \%$ of all local governments reported "lack of competences" as a problem. These were mostly border municipalities, which have no powers to give permission to establish the infrastructure necessary for crossing the state border (border-crossing posts and bridges, telecommunication lines, water, sewage or gas pipelines etc.). These two categories of obstacles were reported in above $7 \%$ of all border twinnings.

\section{The results of cooperation}

Referring to knowledge and information exchange (non-material effects of cooperation). Polish twinned-towns reported such a category of effects as "education, sport and recreation" (80\% of all respondents), "culture" (74\%) and "promotion of tourism" (45\%) (Figure 5). The first two categories were connected mainly to human flows, e.g. the exchange of musical, cultural or drama groups, and the presentation of their achievements, or the exchange of children and youth. Polish local governments most frequently reported the exchange of 40-50 persons yearly ( 1 bus). In border areas in the west and south of Poland formal exchanges were bigger - max. 100-150 persons yearly. Similarly, in the category "Education, sport and recreation", the respondents most frequently reported exchanges of $30-40$ persons yearly. Bigger numbers of 
children and youth exchanges (100-200 individuals) were reported only in 10 towntwinnings. Half of these were twinnings with partners from Western Germany, which was the implication of financial support from the Polish-German Cooperation Foundation. In general, border partnerships reported effects more frequently (Figure 6).

Figure 5. Non-material (knowledge and information) and material (goods and infrastructural investments) effects of bilateral cooperation of Polish municipalities with foreign partners (percentage of partnerships reporting effects in all answers).

$\square$ material effects

$\square$ non-material effects

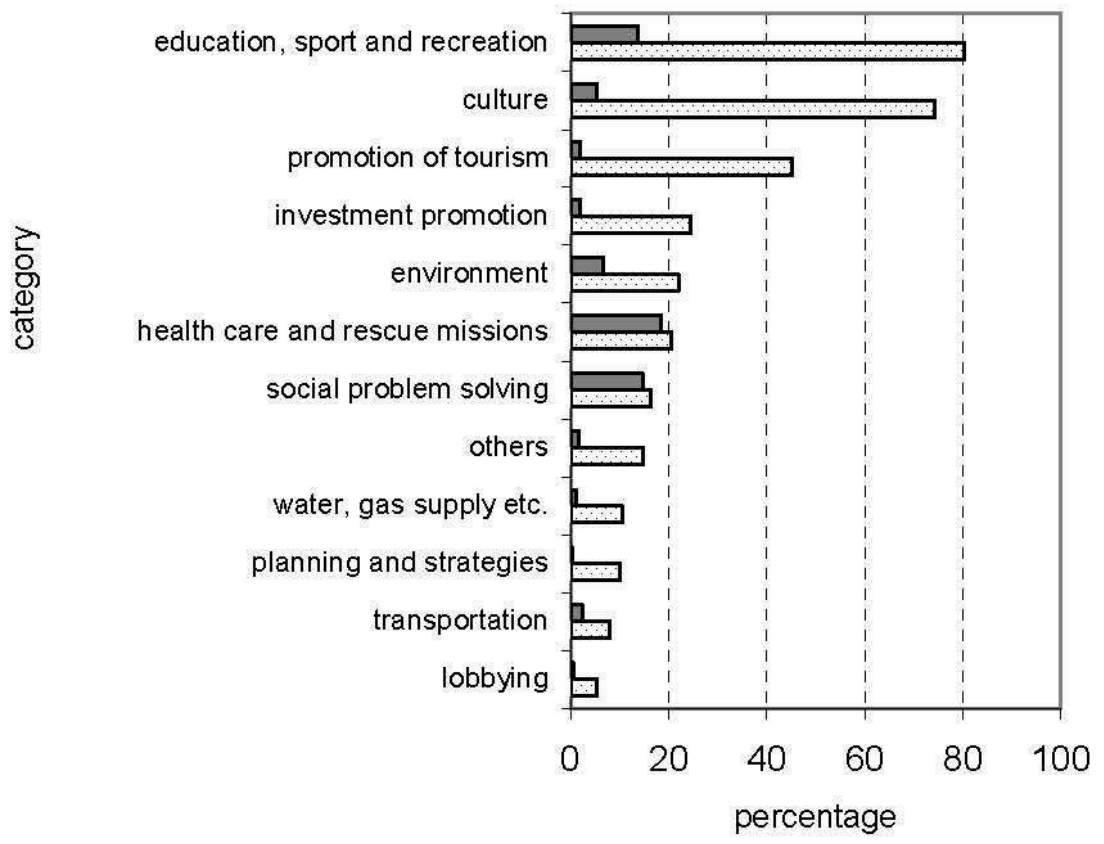

Source: Author's own research 
Figure 6. Percentage of bilateral partnerships reporting non-material effects of cooperation in border and transregional links.

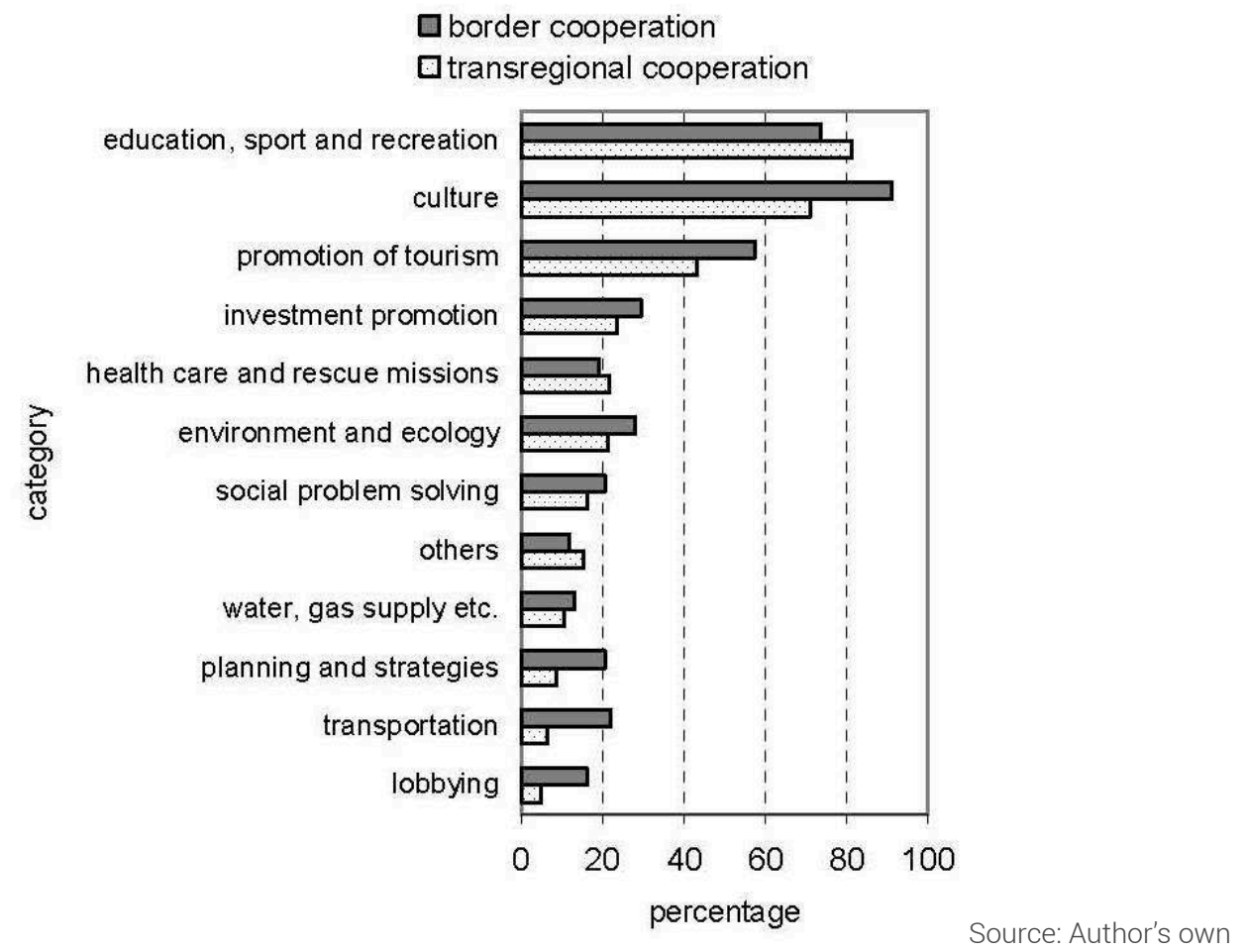

research

In total, $92 \%$ of all the surveyed local governments reported different types of citizen exchange. The most frequently reported exchanges were those with German (159 bilateral contacts, i.e. $43 \%$ of all polled) and French municipalities (10\%), followed by exchanges with partners from the Czech Republic (8.4\%) and Slovakia (5.4\%). From 4.6\% to $3.2 \%$ partners came from Holland, Latvia, Ukraine and Denmark. Except for contacts with neighbouring countries, the strongest relations were those with municipalities from Western Europe (France, Holland, Denmark and Great Britain). Comparing the number of all bilateral contacts and the relations with citizen exchange, we can see higher positions in France, Holland, Denmark and Great Britain in exchange programmes. Partners from Central and Eastern European countries were at the same, or more often at lower positions in the area of human exchange, than in the total number of bilateral contacts. This shows the higher effectiveness of cooperation with partners from Western Europe.

Referring to the material effects of cooperation, 156 bilateral networks (38.8\% of all polled) reported on a minimum of one category of results. These were mainly with partners from Germany (88, i.e. 56\% of all the reported material effects), Holland (12\%), France (7.7\%), Denmark (2.7\%) and Sweden (2.3\%). The most frequent effects belonged to such categories as "health care and rescue missions" (18\% of all partnerships), "social problem solving" (15\%) and "education, sport and recreation" (14\%). These effects were reported more frequently in transregional cooperation (Figure 7). 
Figure 7. Percentage of bilateral partnerships reporting material effects of cooperation in border and transregional links.

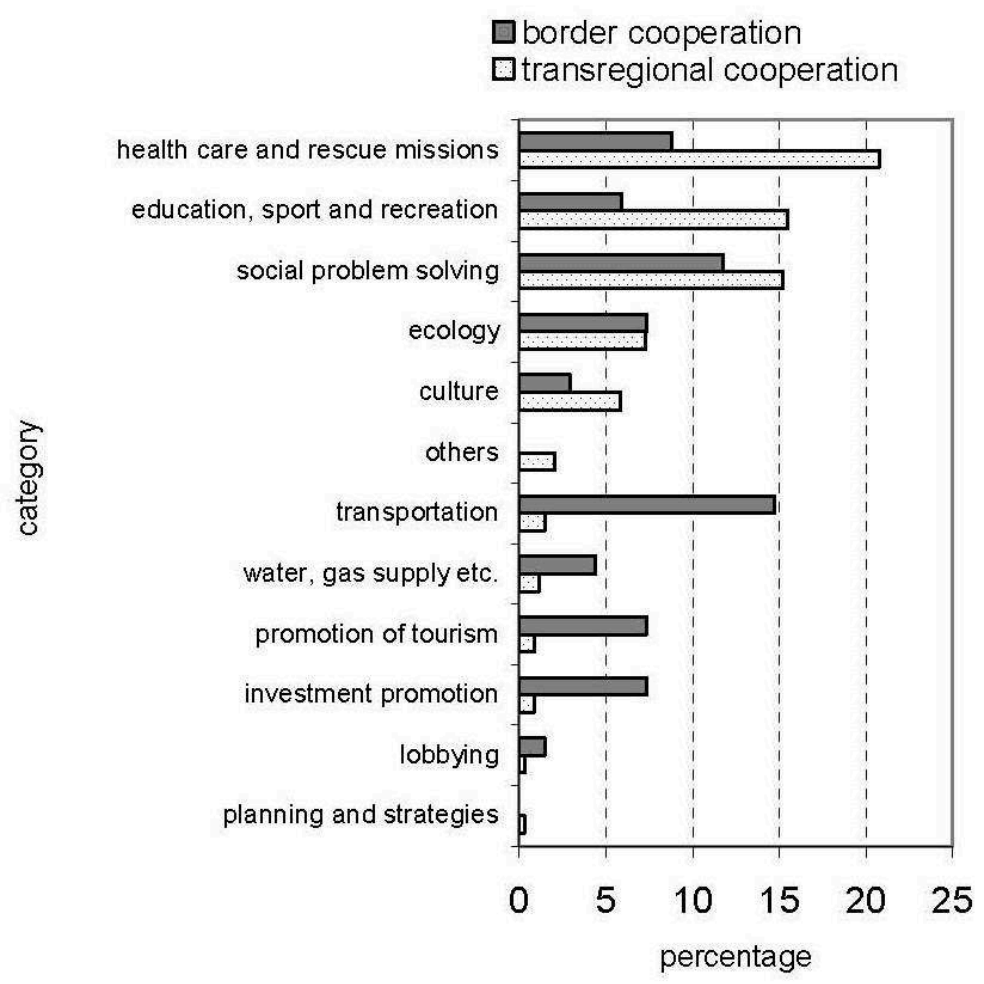

SOURCE: AUTHOR'S OWN RESEARCH 
Figure 8. The share of bilateral partnerships in which exchanges of municipal citizens or officials were reported.

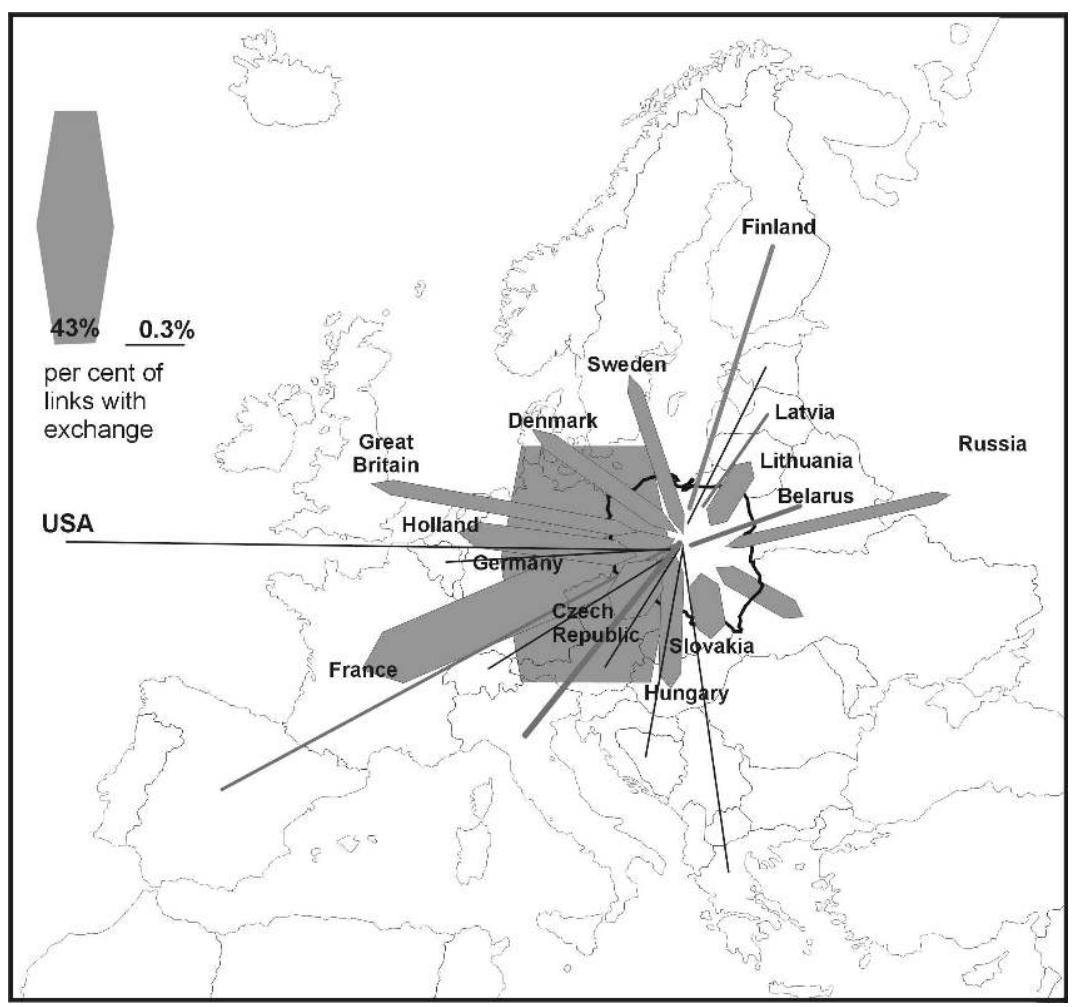

Source: Author's own research "water, gas etc. supply", "tourism" and "investment promotion". It is connected with physical links of border municipalities and greater social connections between them.

In the case of cooperation with Western European countries, goods flowed mainly to Poland. For the most part these were gifts for Polish local communities. In the category "health care and rescue missions" it was medical equipment for hospitals, ambulances, fire engines, rescue equipment etc. Frequently, it was second-hand equipment, but in Polish conditions it was often more modern then that used by Polish institutions or the only available equipment of this type. In the category "social problem solving" these were financial resources for redecoration, computers, furniture and other equipment for orphanages, retirement homes etc., as well as gifts for the poor etc. The category "education, sport and recreation" involved help with redecoration, equipment for schools, sport centres, textbooks for foreign language teaching etc. In several cases, educational or social centres were established thanks to the know-how and financial support (e.g. the Vocational Education Centre in Bielawa based on the German partner's experience). Part of the support was connected to aid provided after the 1997 flood. This was the main kind of occasional support offered to Polish communities by Hungarian, Czech and Slovak partners.

There were reports of some support extended by Polish municipalities to partners in Eastern Europe, mainly to the municipalities inhabited by a Polish minority in Russia, Lithuania, Belarus, Ukraine and the Czech Republic. These were gifts such as textbooks and school equipment, gifts for the poor, financial support for the redecoration of 
Polish schools or cultural centres. Some Polish municipalities helped Czech communities after the floods in 2002.

The only partner outside Europe, with the exchange of goods and persons, was the USA. Due to great distances and the cost of transportation, exchanges with this country are smaller than within the European network.

Future plans of Polish municipalities most frequently involved human exchange (pointed out in $30 \%$ of polled partnerships), cultural events (22\%), initiation of international cooperation of local businesses (19\%), promotion of tourism (10\%), sporting events (8\%), staff and citizen training (7\%) and others (cooperation of public service institutions, solving environmental or social problems, obtaining funds). It is interesting to note the high position of willingness to initiate international business contacts, because this has seldom been reported to date.

Figure 9. The share of bilateral relations with partners from particular countries in the total number of partnerships reporting material effects, and the main directions of goods flow.

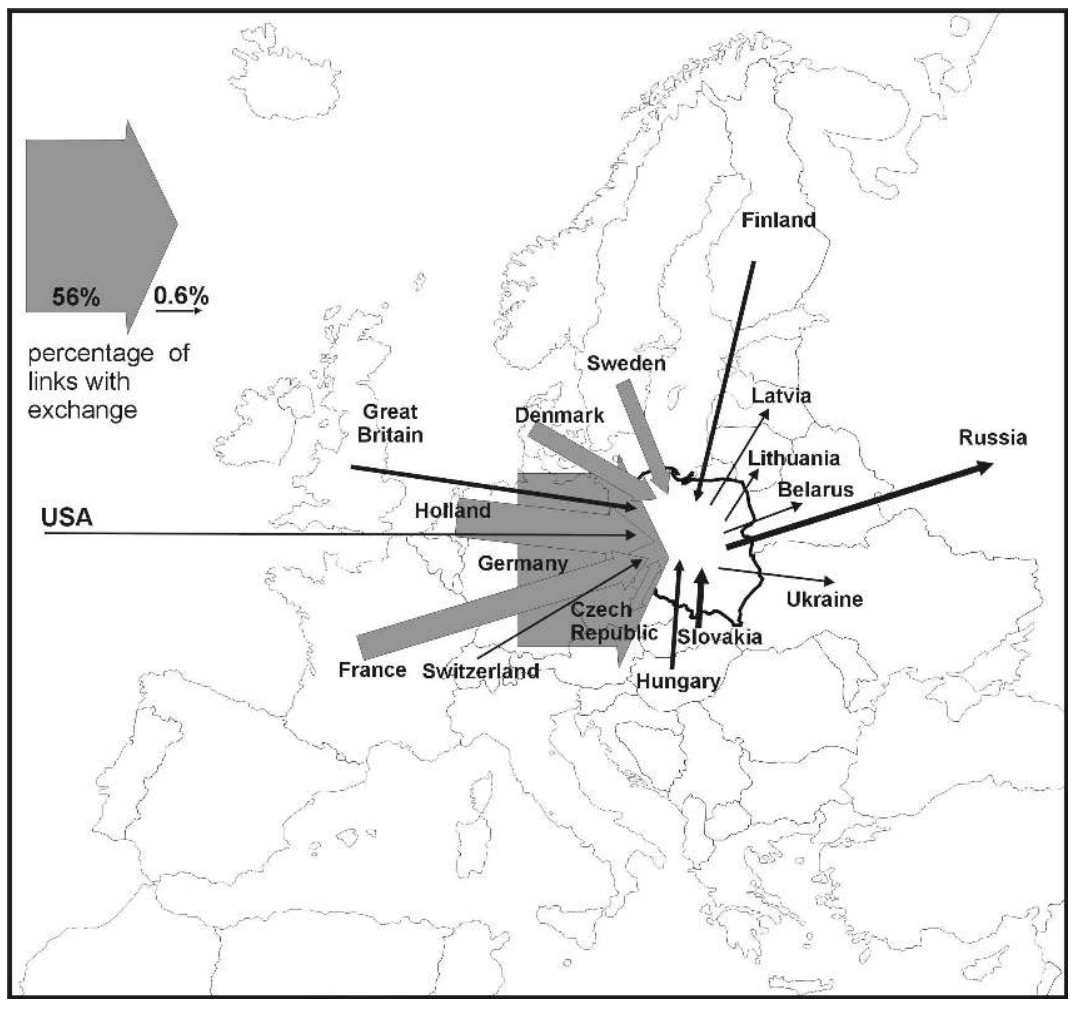

Source: Author's own research

\section{Summary and conclusions}

Considering both cooperation agreements and declarations, as well as the actual flows of people and goods, Polish local governments have the most links with partners from highly developed countries in Western Europe, close by geographically, and with intensive social and economic contacts with Poland. Besides, one can observe a natural gravitation towards the neighbours lying close to the border (also in the case of the sea border), particularly in the borderland area. As a result, regionally, the cooperating units were located mainly in the northern, western and southern parts of Poland. 
ighest level of actual cooperation effects is characteristic of partnerships with Western European countries. Their share in the actual exchange is much higher than the proportion in the total number of declared agreements. The best cooperation results in the area of goods and people exchange have been achieved in the partnerships with German, Dutch, French and Danish municipalities. Human exchange is of a bilateral character, while the flow of goods has so far been dominated by the direction from highly developed countries to Poland. It is typical of most towntwinnings between partners from developing and developed countries (Laurent, 1991; Schep et al. 1995; Hewitt 2000). The assistance of Polish local communities to their foreign partners is limited to administration units in Eastern Europe inhabited by a Polish minority and to single rescue missions organised to help partners in neighbouring countries during natural disasters (e.g. Czech municipalities after the 2002 flood).

The exchange with Western European and Scandinavian countries has been much more significant than that with Southern or Eastern Europe. This is especially due to the strong economic position of Western European countries and the resultant intensive economic and social contacts. The democratic traditions of local self-government in this part of Europe are also of great importance. Local governments of Scandinavian countries are the most active in bilateral cooperation in Europe. In 1995 partnership relations were established by $93 \%$ of all municipalities in Sweden, $84 \%$ in Denmark and 81\% in Finland (Lücke and Bellocchi, 1997). After the 1990 transformation in Poland, it was the local government organisations in Holland, Denmark and Sweden that offered municipal management training for the newly elected local authorities.

wer number of twinning relationships with Russia, Belarus and Ukraine, as well as minor effects of cooperation with these partners result mainly from the shortage of financial resources, political conditions and the absence of local self-government tradition in these countries, as well as from the growing restrictions and tariffs curbing human mobility.

41 German partners strongly dominated, both in the number of formal agreements and in the actual exchange. Possible historic social biases are probably of little significance for establishing and continuing contacts nowadays, since they were not mentioned in any of the obtained questionnaires. The domination of German partners was influenced by a number of factors including (Furmankiewicz, 2001):

- Numerous contacts with Germans related to their tourist mobility, the finding of jobs in Germany by Polish citizens and economic relationships between Poland and this country.

- Historical circumstances resulting in the willingness of German local governments to establish contacts with municipalities in the areas belonging to Germany before World War II, especially when the former inhabitants of now Polish town live in the German municipality, or if there is a German minority in the partner town in Poland.

- A large number of potential partners - in Germany there are over 14,000 self-governing municipalities, of which only 17\% established relationships until 1995 (Lücke and Bellocchi, 1997).

- The relatively well-known possibility to obtain financial support for events and infrastructure projects from the Foundation for Polish-German Cooperation, on condition of having a German partner, and additionally from the Phare-CBC Poland-Germany programme in the case of borderland areas. 
- Functional-spatial links in borderland areas, particularly strong in border-divided cities like

Zgorzelec-Görlitz, Gubin-Güben, Słubice-Frankfurt/Oder (Kostrubiec and Łoboda, 1999). relationships was that of economic factors. It is discernible both in the evaluation of cooperation barriers and in the exchange directions, dominated by relationships with wealthy partners, financially supported by different foundations and programmes. The shortage of financial resources has been the most frequently mentioned barrier to cooperation development, also in other studies (e.g. Żelazo, 2001; Marczuk and Palka, 2002). But considering economic factors, we must remember that business links are usually not much related to the cooperation of local communities (Schep et al., 1995; Hewitt; 2000).

In the present survey, private contacts were the most significant in establishing twinning. This indicates that the directions of town-twinning exchange are mostly the effect of the existing socio-economic relations and the actual human mobility. Although private contacts between local communities are very important, the assistance of various institutions supporting the cooperation financially as well as by information exchange has also a big influence on the flows directions, a factor which has been pointed out by a number of authors (Schep et al., 1995; Budzynowska, 1996; Alger, 1999; Grochowski and Regulska, 2000; Marczuk and Palka, 2002).

Some authors point out an important role of national minorities and immigrant communities in establishing official international relationships between local authorities. These communities intend to maintain contacts with their main cultural areas or their place of origin. The role of such factors was mentioned by J. Zupančič (2001), who described the example of Slovenian minorities in the neighbouring countries and national minorities related to the neighbouring countries in Slovenia. Similarly, S. Weber (1996) mentioned the cooperation of Portuguese towns with municipalities in the areas of Paris, Lorraine, and the north-western industrial region, which all have large groups of Portuguese immigrants, and M. Laurent (1991) quoted the examples of immigrant participation in the establishment of Polish-French partnerships. In the present research, however, this sort of relationship had a clearly secondary role in establishing cooperation on a national scale, in comparison to other reported reasons.

The border and transregional cooperation of Polish municipalities are not really completely different. The sources of cooperation are related to local communities' needs, which are similar in both types of partnerships. The differences are especially small in experience and knowledge exchange. In this research, material social effects were most frequently reported in transregional cooperation. In border cooperation, the effects of cooperation were reported more frequently in such issues as connecting infrastructure (e.g. border crossing and transportation) and promotion. The physical links are most important in divided cities (Kostrubiec and Łoboda, 1999).

In Poland, the biggest cities are the leaders of international cooperation, especially Kraków and Gdańsk. A special case is the local government of the Polish capital city Warszawa (Warsaw), which is really not so active in MIC, considering its biggest potential (Furmankiewicz, 2002). The cooperation and exchange of individual small and medium towns is mostly smaller, but they have greater importance and growing potential due to a great number of such municipalities. 
47 To sum up, the main influence on the directions and character of exchange in twinning relationships of Polish municipalities was that of:

- mobility of local communities, chiefly private contacts of local leaders;

- possibility of financing the exchange by partners and external institutions;

- traditions and the activity of the partner's local government, related to its political conditions.

A characteristic feature of cooperation within twinning relationships is the exchange of information on the partners' culture and local economy. The main philosophy of exchange could be described as "See how we live, get to know us and accept us. See how we manage and solve our problems and use our experience back at home". Towntwinning might cause permanent migrations, but its philosophy prefers chiefly temporary human mobility of an educational character, whose main goal is the exchange of knowledge and information.

\section{BIBLIOGRAPHY}

ALGER CH. F. (1981), Potential of international exchange in building a more participatory world (revised), German Academic Exchange Service (DAAD) International Society for Educational, Cultural and Scientific Interchanges (ISECSI), Wingspread Conference October 3-6, 1981 (manuscript).

ALGER CH. F. (1997), "Japanese municipal international exchange and cooperation in the AsiaPacific: opportunities and challenges", Ritsumeikan International Studies, vol. 9, no. 4, pp. 29-43.

ALGER CH. F. (1999), "The future of democracy and global governance depends on widespread public knowledge about local links to the world", Cities, vol. 16, no. 3, pp. 195-206.

BRZOZOWSKA A. (eds.) (1998), ZwiĄzki Bliźniacze, Współpraca miĘdzynarodowa samorzĄdów lokalnych, ZwiĄzek Miast Polskich, Poznań.

BUDZYNOWSKA O. (1996), “Kontakty bliźniacze nawiĄzywane za pośrednictwem Urzędu Rady Ministrów”, in MOSZCZYŃSKA M., MARGOL K. (eds) Współpraca miast bliźniaczych, Nidzicka Fundacja Rozwoju “Nida”, Nidzica, pp. 23-27.

BURGER L., RAHM D. L. (1996), Sister Cities. In a World of Difference, Lerner Publications Company, Minneapolis.

FURMANKIEWICZ M. (2001), "The international partnership relations of Polish municipalities an example of Lower Silesia”, in KOTER M., HEFFNER H. (eds.), Changing role of border areas and regional policies. Series: Region and Regionalism, 5, Łódź-Opole, pp. 105-114.

FURMANKIEWICZ M. (2002), “Aktywność międzynarodowa samorzĄdów polskich miast wojewódzkich”, in SŁODCZYK J., JAKUBCZYK Z. (eds), ZarzĄdzanie gospodarkĄ miejskĄ i prawne podstawy funkcjonowania miasta, Uniwersytet Opolski, Opole, pp.261-276.

GROCHOWSKI M., REGULSKA J. (2000), "New partnership and collaboration: local government and its supporting institutions - the case of Poland", in AMNÅ E., MONTIN S. (eds.), Towards a new 
concept of local self-government? Recent local government legislation in comparative perspective, Fagbokforlaget, Bergen, pp. 73-100.

HAŁAS K., PORAWSKI A. (2003), Miasta i gminy bliźniacze, UrzĄd Komitetu Integracji Europejskiej, Warszawa.

HANDLEY S. (eds.) (2001), The links effect - a good practice guide to transnational partnerships and twinning for local authorities, International Report 3, Local Government International Bureau, London.

HEWITT W. E. (2000), "International municipal cooperation: An enabling approach to development for small and intermediate urban centers? ", Third World Planning Review, 22, 3, pp. 335-360.

KOĆWIN L. (1993), Polityczne determinanty polsko-wschodnioniemieckich stosunków przygranicznych 1949-1990, Wydawnictwo Uniwersytetu Wrocławskiego, Niemcoznawstwo, t. 3, Acta Universitatis Wratislaviensis No 1535, Wrocław.

KOSTRUBIEC B., ŁOBODA J. (1999), “Le fonctionnement de villes-doublons, departagees par la frontiere polono-allemande”, Images de villes-frontières. Actes du Colloque. Université Luis Pasteur, Strasbourg 7-8-9 April 1999, pp. 164-181.

LAURENT M. (1991), “Des villes françaises jumelées avec des villes polonaises”, Hommes et Terres $d u$ Nord, 1, Université des Sciences et techniques de Lille, Lille, pp. 15-16.

LÜCKE B., BELLOCCHI E. (eds.) (1997), A Europe of towns and cities. A practical guide to town-twinning, Office for Official Publications of the European Communities, Luxembourg.

MARCZUK S., PALKA J. (2002), “Cross-border cooperation within the Carpathian Euroregion”, in BORLAND J., DAY G., SOWA K. Z. (eds.), Political borders and cross-border identities at the boundaries of Europe, Wydawnictwo Uniwersytetu Rzeszowskiego, Rzeszów-Bangor, pp. 93-101.

MARKOWIAK A. (1997), “Transborder cooperation of Polish and Czech municipalities on the example of Racibórz and Opava", The situation and perspectives of transborder development and cooperation of border regions in Germany, Poland, Slovakia and the Czech Republic, Papers presented at an international conference in Gliwice $13^{\text {th }}-16^{\text {th }}$ February 1997, Gliwice, pp. 103-109.

SCHEP G., ANGENENT F., WISMANS J., HILLENIUS M. (1995), Local challenges to global change, SDU Publishers, The Hague.

TRZCIELIŃSKA-POLUS A. (1997), “Współpraca Opole-Poczdam. Kilka refleksji na marginesie artykułu o narzuconej przyjaźni miĘdzy PolskĄ a NRD”, Studia ŚlĄskie, t. LV, Opole, pp. 375-391.

WEBER S. (1996), “Ruch miast bliźniaczych w Europie i w Polsce”, in MOSZCZYŃSKA M., MARGOL K. (eds), Wspótpraca miast bliźniaczych, Nidzicka Fundacja Rozwoju „Nida”, Nidzica, pp. 7-11.

ZELINSKY W. (1991), “The twinning of the world: sister cities in geographical and historical perspective", Annals of the Association of American Geographers, 81, 1, pp. 1-31.

ZUPANČIČ J. (2001), “Spatial function of dispersed minorities”, in KOTER M., HEFFNER H. (eds.), Changing role of border areas and regional policies. Series: Region and Regionalism, No 5, Łódź-Opole, pp. 228-240.

ŻELAZO A. (2001), "Samorząd gminny w stosunkach miĘdzynarodowych. Pierwsze przybliżenie", Polski Przegląd Dyplomatyczny, 1, 2, Polski Instytut Spraw MiĘdzynarodowych, Warszawa, pp. 21-60. 


\section{ABSTRACTS}

Town-twinning is a form of Municipal International Cooperation (MIC). It enables local communities to share experience and innovation in the field of town and municipality management techniques and encourages people to follow the tendency to remove political barriers. It generates flows of goods and people as a part of an exchange initiated by local governments and organised with their assistance. In the past decade, the international cooperation of local governments in Poland generated mainly the exchange of information, goods and people with Western Europe and Scandinavian countries (64\% of all links in 2001), mainly with Germany, France, Holland and Denmark. The main directions of goods and information flows were from highly developed countries to Poland. Only human (cultural) exchange was really bilateral. If we do not take into account the border cooperation with neighbouring countries, the institutional connection links with Eastern, Southern and Central Europe were very weak. This shows and confirms the dominance of parallel connections in this part of Europe, whose strength decreases going eastwards. These flows contributed to the integration of Poland with Western Europe. The most common barrier was lack of financial resources, and the most frequently chosen partners were richer ones. Private contacts with local leaders had the highest importance in linking the partners. This shows that the directions of twinned municipality exchanges are above all the result, and not the source, of existing social and economic relationships.

Le jumelage des villes est une forme de Coopération Municipale Internationale (CMI). Il permet à des communautés locales de partager certaines expériences et innovations dans le domaine des techniques de gestion des villes et des municipalités et encourage la tendance à abolir les barrières politiques.Le jumelage genère des flux de biens et de personnes dans le cadre d'échanges mis sur pied par les gouvernements locaux et organisés avec leur assistance. Durant la dernière décennie, la coopération internationale de gouvernements locaux en Pologne a principalement suscité l'échange d'information, de biens et de personnes avec l'Europe de l'Ouest et les pays scandinaves (64\% de l'ensemble des échanges en 2001), en particulier l'Allemagne, la France, la Hollande et le Danemark. Les biens et l'information ont surtout été orientés vers la Pologne à partir de pays hautement développés. Seuls les échanges "humains" (culturels) ont été de réels échanges bilatéraux. Si l'on exclut la coopération frontalière avec les pays voisins, les rapports institutionnels avec l'Europe de l'Est, du Sud et l'Europe Centrale sont restés très limités. Ceci montre et confirme la prédominance de liens parallèles dans cette partie de l'Europe, décroissants toutefois en direction de l'est.Ces flux contribuent à intégrer la Pologne dans l'Europe de l'Ouest. On notera que le principal obstacle est constitué par le manque de ressources financières, et que les partenaires les plus fréquemment choisis sont en général mieux nantis. Les contacts d'ordre privé avec des dirigeants locaux se sont avérés de la plus haute importance dans l'établissement des échanges entre partenaires. Ceci montre que l'orientation des échanges en matière de jumelage de municipalités résultent en premier lieu de relations socio-économiques déjà établies plutôt que d'en être l'origine.

\section{INDEX}

Mots-clés: gouvernement local, coopération internationale, flux humains et matériels, Pologne

Keywords: local government, international cooperation, human and goods flows, Poland 


\section{AUTHOR}

\section{MAREK FURMANKIEWICZ}

Wrocław University, Institute of Geography and Regional Development, marfurm@interia.pl 